\title{
Geological conditions of the distribution of closed depressions in the Nałęczów Plateau (Lublin Upland, E Poland): are they an origin determinant?
}

\author{
Renata Kołodyńska-Gawrysiak, Marian Harasimiuk, Łukasz Chabudziński, \\ Waldemar Jezierski, Małgorzata Telecka
}

Faculty of Earth Sciences and Spatial Management, Maria Curie-Skłodowska University in Lublin, Poland; renata.kolodynska-gawrysiak@poczta.umcs.lublin.pl

\begin{abstract}
Closed depressions (CDs) are landforms typical for loess areas. 1761 CDs have been inventoried within the Nałęczów Plateau. Large concentrations of CDs: $30-40$ forms per $\mathrm{km}^{2}$ occur in areas where thick (more than $10 \mathrm{~m}$ ) complex of glacigenic sediments (mainly glacial tills) or clay (limniglacial) deposits underlying loess cover. Areas with a low concentration of CDs (fewer than 10 forms per $\mathrm{km}^{2}$ ) correspond to areas where the loess cover lies on a bedrock (opokas) or on thin sandy-gravelly deposits. The distributions of CDs depends on the conditions of Pleistocene permafrost development and melting, linked with lithological properties of the sediments under loess cover.
\end{abstract}

Key words: closed depressions, loess, glacial tills

\section{Introduction}

Closed depressions (CDs) rank among the most common surface features in loess areas (Maruszczak 1954). Polish geomorphological literature refers to them as werteby or wymoki (Maruszczak 1954, Czarnecki, Lewartowska-Urbańska 1987). The latter is a popular name referring to the function played by closed depressions in the landscape, i.e. the periodic accumulation of surface water in the depressions, during the spring snowmelt or prolonged rainfall, which results in the soaking (pol. wymakanie) of the crops. Studies by Maruszczak (1954) revealed that depressions are characterised by a variety of hydrologic regimes, and on this basis three types of depressions can be distinguished: a) with stagnant water, b) with periodic water, c) with temporary water. In Poland, closed depressions were studied in the loess areas of the Lublin Upland (Maruszczak 1954, Konecka-Betley, Maruszczak 1993, Kołodyńska-Gawrysiak, Chabudziński 2012, Kołodyńska-Gawrysiak et al. 2012), Sandomierz Upland (Czarnecki, Lewartowska-Urbańska 1987, Czarnecki, Solnceva 1992) and Kolbuszowa Plateau (Wojtanowicz 1997).

According to the theory on the origin of depressions, proposed by Maruszczak (1954) and maintained with re- gard to Polish territory by other researchers in the 1980s and 1990s, closed depressions formed in the postglacial period as a result of piping processes within the initial depressions linked with the dynamics of the loess cover sedimentation and the early stages of its transformation (Maruszczak 1954). Small polygenetic closed depressions were investigated also in the Polish Lowland, where contribution of periglacial processes in their origin were documented (Stankowski 2012). Similar forms were observed in loess cover in Russia, Belarus and Ukraine (Zanin 1952, Makeev 2009).

Closed depressions were also studied in France (Pissart 1958), the United Kingdom (Prince 1961) and central Belgium (Gillijns et al. 2005, Vanwalleghem et al. 2007). A review and summary of the opinions to date on the origins of closed depressions in the loess areas of Western Europe appeared in a recently published study (Etienne et al. 2011). Not ruling out the possibility of the natural origin of closed depressions, its authors indicate that the origin of the forms studied and described within the loess covers of Western Europe is exclusively linked with human activity (loess extraction, animal husbandry), and they should be dated to the Subatlantic period (Etienne et al. 2011). 


\section{Study objective and methods}

The study objective is to carry out a qualitative and quantitative assessment of the impact of lithological characteristics of the loess parent material and thickness of the loess cover on the distribution of closed depressions in the Nałęczów Plateau in the context of the origin of these forms.

The first stage of the study consisted of obtaining geological information, based on geological and hydrogeological drilling data kept in the HYDRO Bank of the State Hydrogeological Service, for the Nałęczów Plateau and its several kilometre-wide buffer zone. The database prepared in an Excel spreadsheet was supplemented with geological borehole and profile data prepared for the published and unpublished sheets of the Detailed Geological Map of Poland, scale 1:50 000, sheets: Lublin, Kazimierz Dolny, Kurów and Nałęczów. From the entire spectrum of data contained in the geological and hydrogeological documentation, information was selected concerning the location of the boreholes as well as the borehole/depth characteristics and lithostratigraphic characteristics of the profiles. Based on the 1:300 000 geomorphological map by Maruszczak (1964) and 1:10 000 topographical maps, geological profiles were selected based on geomorphological location in order to eliminate profiles located in the bottoms of river valleys.

Subsequently, the borehole descriptions were analysed in detail in order to carry out the lithological-genetic interpretation of sediments recorded in the individual geological profiles. Five main lithological-genetic types of sediments were distinguished: loesses, glacigenic sediments with the predominance of glacial till, sandy sediments of various origin, clays and loams of various origin, bedrock.

In the second stage, spreadsheet data were converted in the spatial data format into an .shp file. The file was generated in the PUWG92 system and it contained information on the spatial location of the forms, the geological formations, their thickness and depth at which they occur. Based on a database containing 239 forms, the thickness and the depth at which the individual types of sediment occurred were interpolated. On that basis, the following maps were prepared: thickness of Quaternary deposits, thickness of loess, and thickness of glacigenic sediments. The interpolation was carried out using ArcGIS 10.0 software and the Topo to Raster tool.

In the final stage, statistical analyses were carried out with regard to the quantitative assessment of the correlation between the distribution of the depressions and the main lithological-genetic types of the sediments. The statistical analysis was conducted using the Pearson method and linear regression method, using the symbolic algebra program Methematica. The analysis was based on counting the number of depressions for the previously adopted thickness values of the individual lithological-genetic types of sediments, and then determining the percentage share of areas with a given sediment thickness. Based on these data, the potential number of depressions occurring in the study area was estimated assuming that it was covered with a sediment layer of a specific thickness. These computations were carried out for each range of sediment thickness.

\section{Morphometric properties of closed depressions}

1761 closed depressions have been inventoried within the Nałęczów Plateau.

Most of them (69\% of the total number) are depressions with an area up to $1500 \mathrm{~m}^{2}$. Nearly three quarters of these are depressions smaller than $1000 \mathrm{~m}^{2}$. The size of $17 \%$ of the depressions is between 1500 and $2500 \mathrm{~m}^{2}$. The remaining depressions are within four size ranges, each accounting for less than $10 \%$.

The longer axis of most depressions $(85.74 \%$ of the total number) is up to $80 \mathrm{~m}$ long. The longer axis of nearly two thirds of depressions in this group ranges from 25 to $50 \mathrm{~m}$. They account for more than half $(51.39 \%)$ of all closed depressions in the region.

An overwhelming majority of the closed depressions are shallow as their present-day depth is not more than $1.25 \mathrm{~m}$ : they account for more than $96 \%$ of all the depressions under study. Depressions up to $2.5 \mathrm{~m}$ deep account for just over $3 \%$ of all the depressions under study.

A vast majority $(82.16 \%)$ of the closed depressions in the Nałęczów Plateau are oval-shaped. The remaining $17.7 \%$ of the depressions have irregular shapes. The closed depressions in the Nałęczów Plateau are characterised by gentle outlines resulting from the lack of distinct boundaries separating the slopes and floors of the individual depressions.

\section{The main features of the geological structure of the Nałęczów Plateau}

The bedrock of the Nałęczów Plateau consists of Upper Cretaceous and Palaeocene rocks. Among the Cretaceous rocks, the rocks of the youngest stage of the Upper Cretaceous, i.e. Upper Maastrichtian, have the greatest significance for the geological structure of the area. These rocks show great lithological diversity and the following types can be distinguished: opokas, gaize rocks, marls, limestones and marly limestones. The Upper Cretaceous rocks form a monocline dipping at 3 to 5 degrees towards the $\mathrm{NE}$, and are dissected by dislocations of varying order, the NW-SE orientation predominating, and a system of joints. An important role in the structure of the top part of the bedrock in the study area is played by Palaeocene rocks represented mainly by limestones, gaize rocks, opokas, sands and glauconitic sandstones. Patches of Oligocene sandy and sandy-loamy deposits occur on the rocks of the Cretaceous-Palaeocene complex (Harasimiuk et al. 2008).

Quaternary sediments, including glacigenic deposits and loess of varying thickness, lie on the bedrock charac- 
terised by varied relief. The glacigenic deposits are represented by two layers of glacial till from the Elsterian 2 and Odranian Glaciation as well as sandy and sandy-gravelly fluvio-glacial sediments, limniglacial clays and loams accumulated during the Odranian Glaciation (Jahn 1956, Harasimiuk, Henkiel 1978, Harasimiuk 1987).

The loess cover of the Plateau is not continuous: several loess patches of varying size are separated by rivers valleys where loess does not occur. The thickness of the loess cover varies both at the scale of the region and within the individual patches. It reaches maximum values in the western part and along the northern boundary of the region (up to $30 \mathrm{~m}$ ). The thickness of the loess cover usually decreases towards the east and south. In the eastern part of the Nałęczów Plateau, the loess cover is usually 10 to $20 \mathrm{~m}$ thick. The highest-lying areas of this part of the region (more than $220 \mathrm{~m}$ a.s.1.) are covered by a loess layer more than $20 \mathrm{~m}$ thick. In the narrow zones along the valleys, the loess cover is not more than $10 \mathrm{~m}$ thick (Harasimiuk 1987). The loess cover conceals small forms of the loess parent material and mirrors the basic elements of its relief (Harasimiuk, Henkiel 1978).

According to Maruszczak's (2001) loess stratigraphic scheme, these sediments belong to younger loess that accumulated during the Weichselian Glaciation from ca. $50000 \mathrm{BP}$ to $18000 \mathrm{BP}$ and to older upper loess (Lsg) that accumulated during the Saalian II Glaciation (150 000 BP).

Older upper loess, documented only in the western part of the region, is overlain by a thick complex of younger loess consisting of four layers of varying thickness, namely the lowest younger loess (LMn), lower younger loess (LMd), middle younger loess (LMs) and upper younger loess (LMg) (Harasimiuk, Jezierski 2001). LMg, occurring in the top part of the loess complex, is the thickest layer (more than $10 \mathrm{~m}$ ). The eastern part of the Nałęczów Plateau is covered by a complex of younger loess consisting of three layers: lower younger loess (LMd), middle younger loess (LMs) and upper younger loess ( $\mathrm{LMg}$ )
(Harasimiuk 1987). In many places, loess lies directly on the bedrock.

\section{The distribution of the closed depressions in the Nałęczów Plateau}

Most of the closed depressions (72\%) are concentrated within the plateau tops, and $67 \%$ of these are situated within the range from 210 to $230 \mathrm{~m}$ a.s.l. (Fig. 1, 2). Fewer depressions occur within denudation troughs $(16 \%)$ and erosion-denudation valleys (13\%).

The distribution of closed depressions in the Nałęczów Plateau is uneven and the clear differences occurring between the eastern and western part of the region in this respect correspond to the landform characteristics peculiar to both areas. The largest number of depressions occur in the eastern part of the Nałęczów Plateau (Fig. 3) dissected by valley and gully systems to a lesser degree than the western part, hence much less drained and having different hydrogeological determinants (Harasimiuk, Gawrysiak 2012). The predominant element of landscape

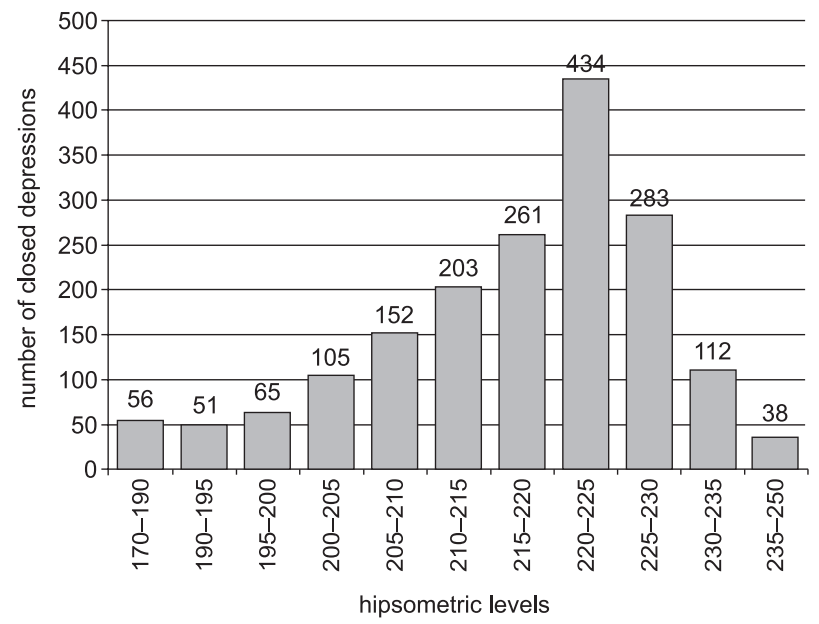

Fig. 2. Number of closed depressions in hypsometric levels of the Nałęczów Plateau

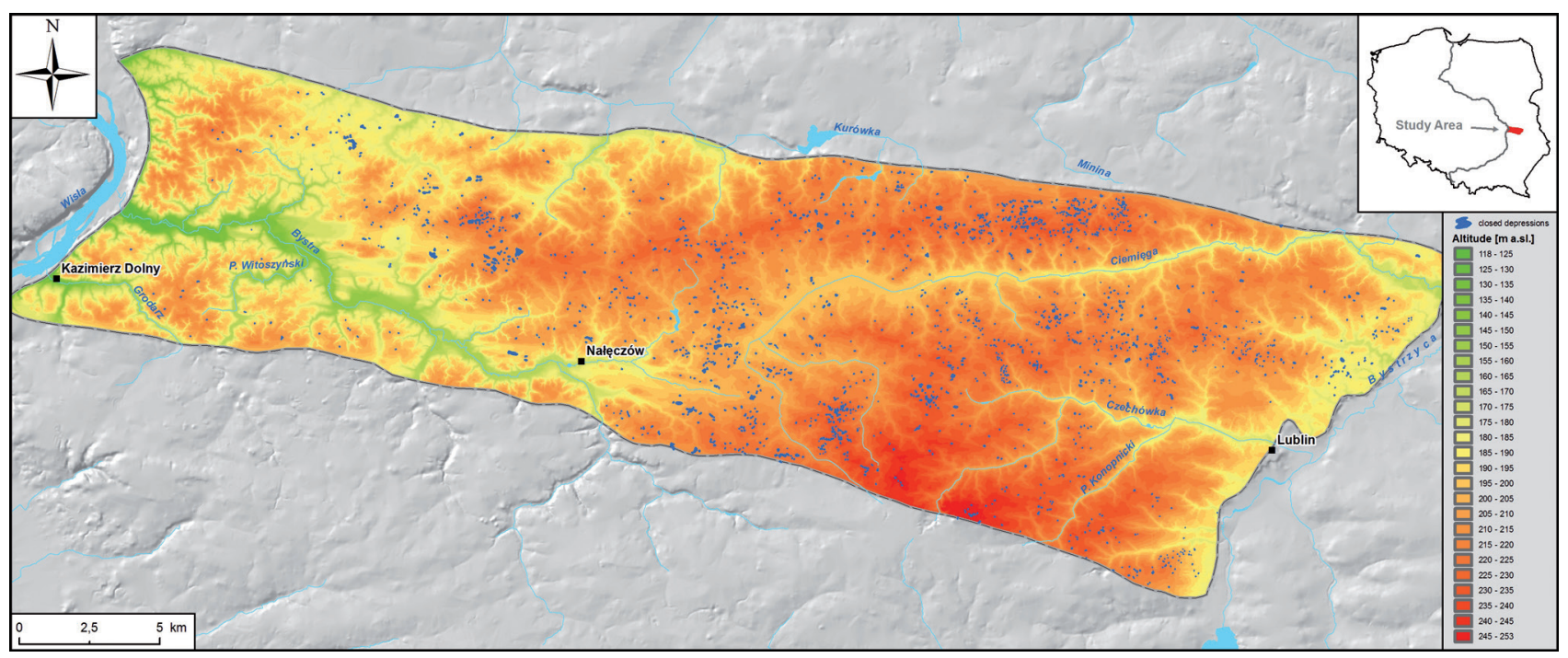

Fig. 1. Distribution of closed depressions in relation to hypsometric levels of the Nałęczów Plateau 


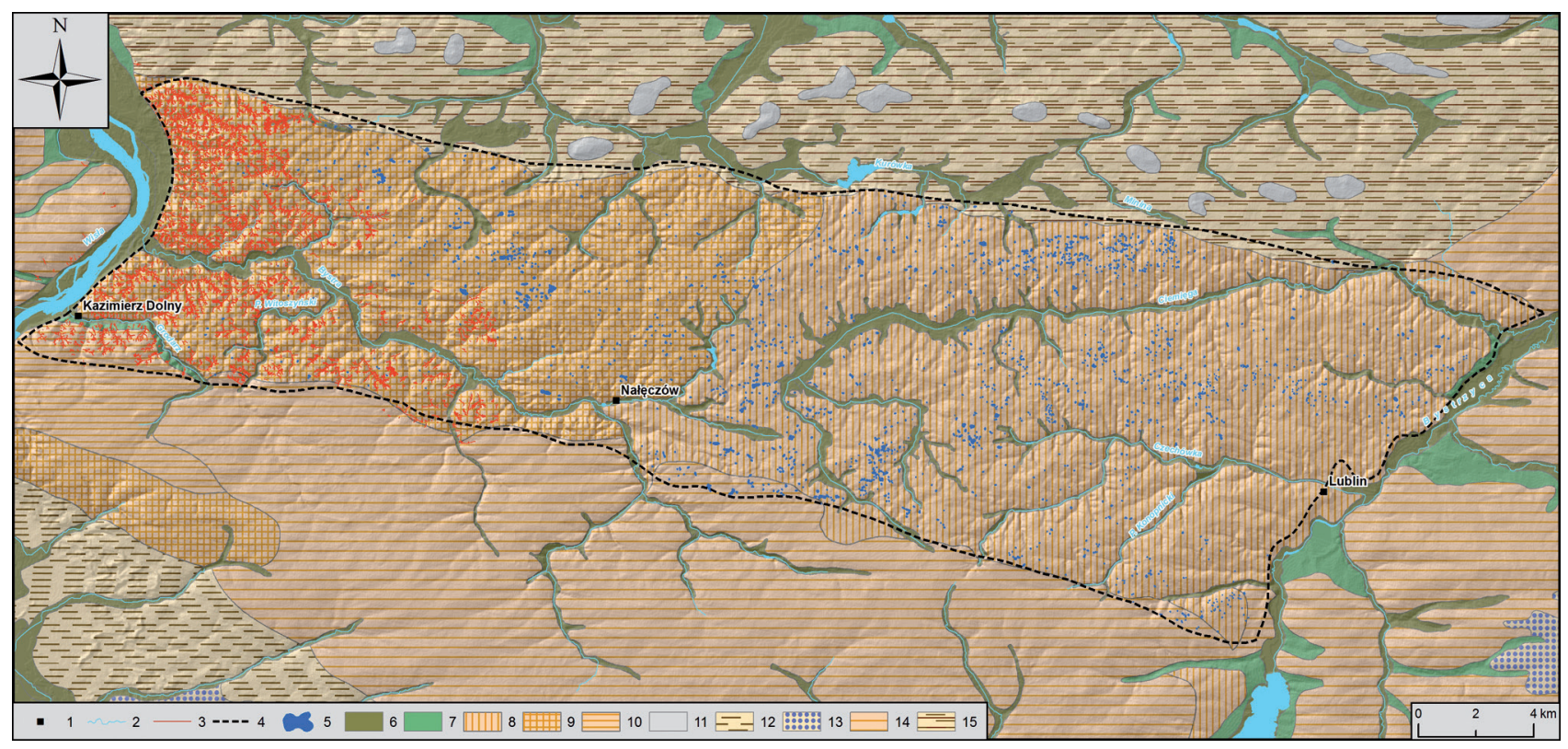

Fig. 3. Distribution of closed depressions against a geomorphological map of the Nałęczów Plateau (after Maruszczak 1964, altered) 1 - towns, 2 - rivers, 3 - gullys, 4 - border of the Nałęczów Plateau, 5 - closed depressions, 6 - bottoms of the river valleys and basins, 7 - terraces in the river valleys, 8 - loess covers poorly incision by dry valleys and gullys, 9 - loess covers heavy incision by dry valleys and gullys, 10 - hummocky surface on the opoka bedrock 11 - hills of glacigenic deposits, 12 - plains on fluvioglacial deposits, 13 - karst sinkholes, 14 - hummocky surface on the marl bedrock, 15 - rolling plain on glacigenic deposits

in the eastern part are vast undulating loess plateau areas with numerous closed depressions (Fig. 3). The depressions are particularly abundant in areas between the Ciemięga and Kurówka rivers and between the Ciemięga and Minina rivers. In this distinct continuous area, the concentration of the depressions exceeds 10 forms per $\mathrm{km}^{2}$ and, in some places, it reaches 40 forms per $\mathrm{km}^{2}$ (Fig. 4). A large concentration of depressions also occurs in the vast watershed area of the Ciemięga and Czechówka rivers where the index reaches 30 forms per $\mathrm{km}^{2}$ (Fig. 4). A considerable concentration of depressions (more than 10 forms per $\mathrm{km}^{2}$ ) also occurs in a small area in the upper reaches of the Ciemiega catchment, near the localities of Kolonia Tomaszowice and Kolonia Miłocin where the index reaches 40 forms per $\mathrm{km}^{2}$, a maximum value at regional scale. An extensive and rather continuous area with a large concentration of depressions (up to 20 forms per $\mathrm{km}^{2}$ ) occurs in the vicinity of Sadurki, Marianka Ożarowska and Miłocin. Small areas where concentrations of depressions reach similar values (20 forms per $\mathrm{km}^{2}$ ) occur in the vicinity of Stasin and Pliszczyn Kolonia (Fig. 4).

Closed depressions are less numerous in the western part of the Nałęczów Plateau. In the western end of the

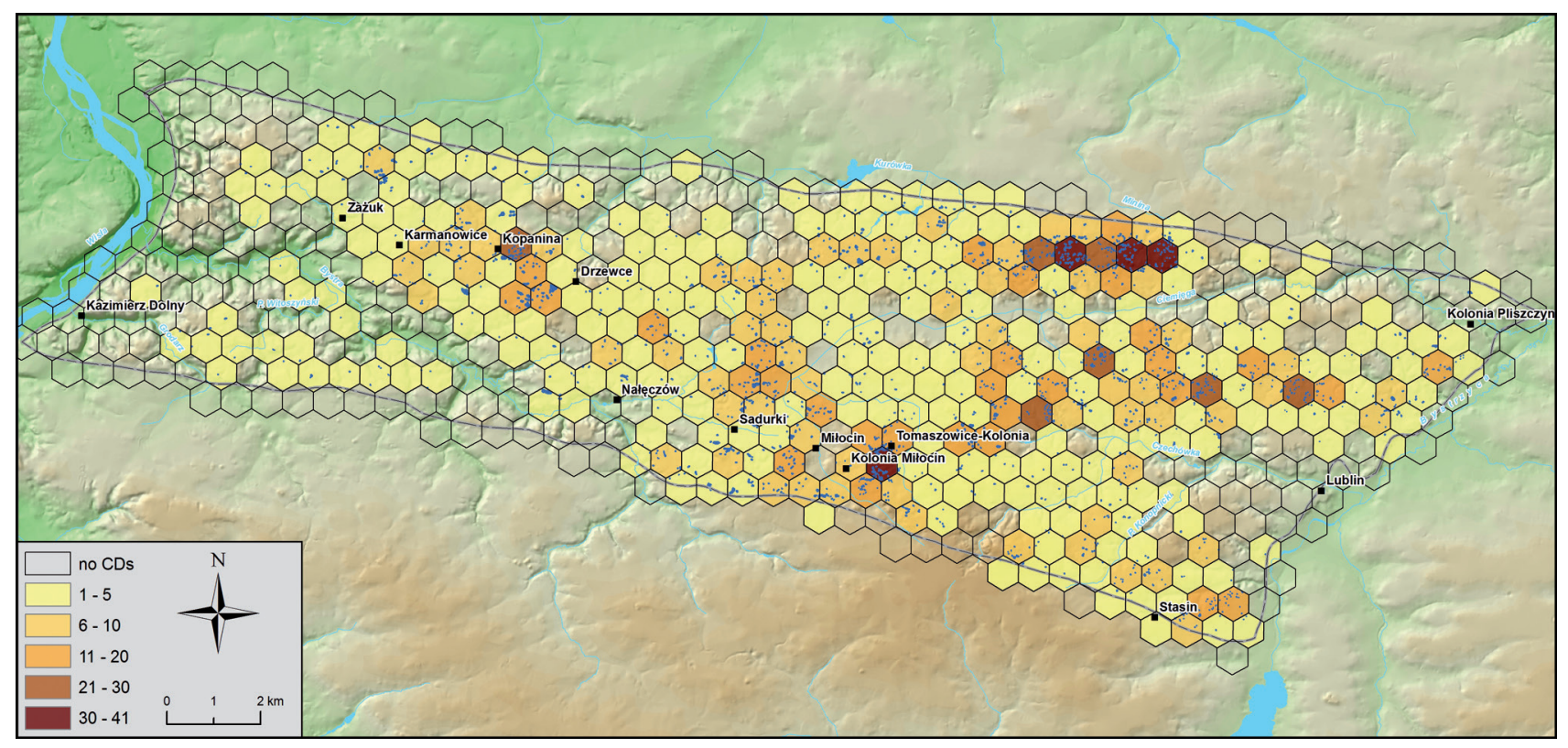

Fig. 4. Concentration of closed depressions in the Nałęczów Plateau (number of CDs per $\mathrm{km}^{2}$ ) 


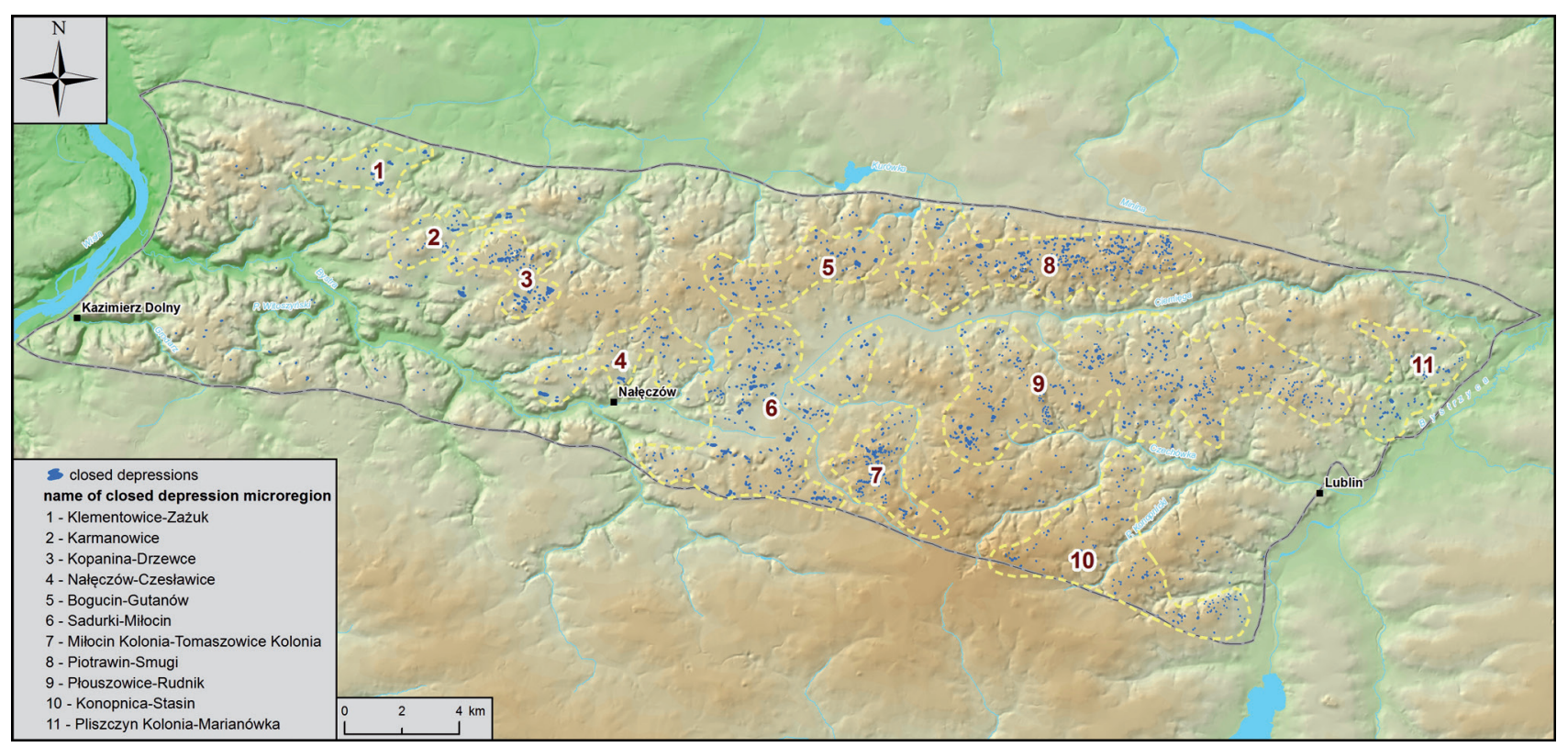

Fig. 5. Closed depressions microregions in the Nałęczów Plateau

Plateau, adjoining the Vistula river, closed depressions practically do not occur at all (Fig. 3). This area is densely riddled with erosion-denudation valleys deeply incised into the bedrock and dissected by gully systems. Areas with a high concentration of closed depressions (more than 10 forms per $\mathrm{km}^{2}$ ) occur rarely in the western part of the Plateau and are linked with more extensive plateau top patches (Fig. 3). The development of gullies contributed to considerable dissection of the loess plateau tops whose small fragments were preserved as part of rather narrow ridges between valleys. The concentration of closed depressions reaches $10 / \mathrm{km}^{2}$ only within a small area in the vicinity of Zażuk, Kolonia Klementowice and Karmanowice (Fig. 4). In the vicinity of Drzewce, the concentration of closed depressions reaches 20 forms per $\mathrm{km}^{2}$ and in the environs of the nearby village of Kopanina it reaches 30 forms per $\mathrm{km}^{2}$ (Fig. 4).
In the Nałęczów Plateau, there are continuous areas with high concentrations of depressions, exceeding 10 forms per $\mathrm{km}^{2}$ and reaching as many as 30 to 40 forms per $\mathrm{km}^{2}$. At the scale of the entire region, 11 areas described as closed depressions microregions were distinguished (Fig. 5). They are distinguished based on many individual morphometric characteristics and distribution types of closed depressions (Kołodyńska-Gawrysiak, Chabudziński 2012). Most of the closed depressions microregions (7) are situated in the eastern part of the Nałęczów Plateau and extend over large areas up to $40 \mathrm{~km}^{2}$ in comparison with the western part of the region where similar areas cover not more than $8 \mathrm{~km}^{2}$ (Kołodyńska-Gawrysiak, Chabudziński 2012).

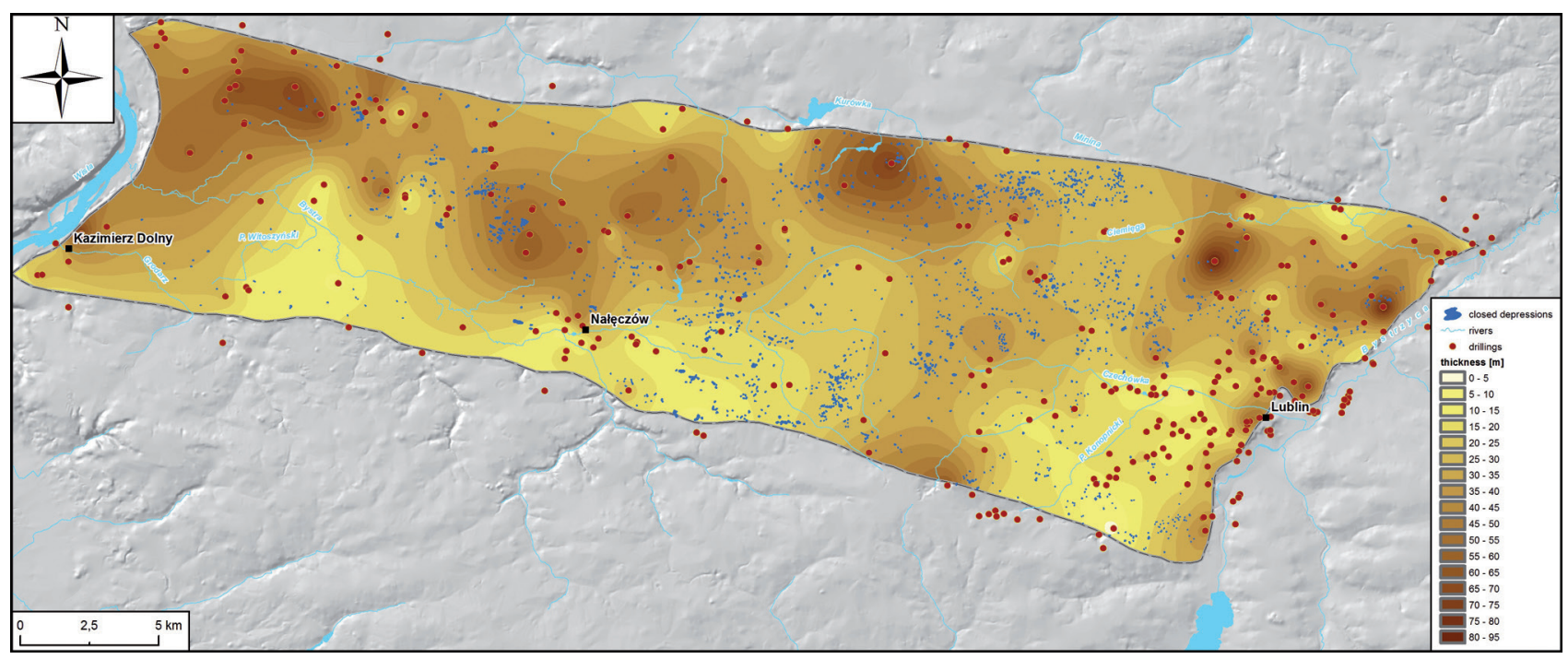

Fig. 6. Thickness of Quaternary sediments 


\section{Description of the main litho-genetical types of Quaternary sediments}

The thickness of the Quaternary sediment series in the Nałęczów Plateau is uneven, ranging from 5 to $95 \mathrm{~m}$. The thickest series occur in a distinct, continuous, arch-shaped zone extending to the north of the Ciemięga and Bystra valleys (Fig. 6). Another zone of this type, more irregular in shape, occurs in the north-eastern part of the area between the Ciemięga and Czechówka rivers (Fig. 6). Areas where Quaternary sediments are less than 20 thick occur in the southern forefield of these zones (Fig. 6).

\section{Complex of glacigenic sediments with a predominance of glacial till}

These sediments are represented by glacial series whose thickness ranges from several to $80 \mathrm{~m}$. They mostly consist of glacial till with interbedded gravelly, sandy and loamy-clayey sediments that accumulated during the Elsterian 2 and Odranian Glaciation. Glacial sediments that accumulated during the Odranian Glaciation have the greatest share among them. The Odranian series were forming as a result of complex processes taking place during the recession of the Odranian ice sheet. They represent varied sedimentation environments linked with the phases of the recession of that glaciation. Thick glacigenic series (more than $20 \mathrm{~m}$ thick) occur north of the Ciemięga and Bystra valleys. They form a distinct zone whose arched shape along with the $50 \mathrm{~m}$ thick sediments and peculiar morphological features suggests that it is a loess-covered marginal zone linked with one of the recession phases of the Odranian ice sheet (Harasimiuk, Henkiel 1976, Harasimiuk 1987).

Quite thick glacigenic sediments also occur along the eastern boundary of the region, marked by the Bystrzyca valley. Within this highly irregular zone, glacigenic sediments are usually more than $20 \mathrm{~m}$ thick, reaching the maximum thickness of the $80 \mathrm{~m}$ in the northern part of the area between the Czechówka and Ciemięga rivers $(\mathrm{Bu}-$ trym et al. 1980).

There are few areas where the thickness of glacigenic sediments is small, not more than $5 \mathrm{~m}$. An area of this type, well documented with numerous boreholes, is located in the eastern part of the region encompassing the central area between the Czechówka and Bystrzyca rivers and the valley sides in the lower reaches of the Ciemiegga river. In the western part of the region, glacigenic sediments showed a minimum thickness on the sides of the valleys of the Potok Witoszyński and the middle reaches of the Bystra, both deeply incised into the bedrock. Areas where glacigenic sediments are not more than $20 \mathrm{~m}$ thick predominate in the region, particularly in the eastern part of the Plateau. The glacigenic sediments constitute the parent material for the loess in a greater part of the region.

\section{Complex of clayey-loamy sediments of various origin}

This category includes sediments representing various glacial and periglacial sedimentation environments with the predominance of accumulation in ice-marginal lakes. The thickest series of these sediments, more than $10 \mathrm{~m}$, and up to $28 \mathrm{~m}$ locally, were recorded in the western part of the region in an area north of the Bystra valley between Parchatka and Klementowice. This complex reaches considerable thickness, from 5 to $10 \mathrm{~m}$, in the southern part of the area between the Bystra and Ciemięga rivers (the environs of Sadurki) and the upper reaches of the Ciemięga catchment (the environs of Miłocin and Tomaszowice). These sediments lie on sands, glacigenic sediments and the bedrock. In a few profiles, several metres thick, clayey-loamy sediments were documented under glacial deposits or sand deposits. They probably represent the older limniglacial complex associated with the Elsterian 2 Glaciation.

\section{Sandy sediments of various origin}

They were found in various parts of the region where they usually occur as highly irregular patches up to $15 \mathrm{~m}$ thick. Sediments of this type represent varied sedimentation environments, both fluvial and fluvio-glacial, functioning in the interglacial and glacial/periglacial conditions of the Quaternary respectively.

In the profiles studied, these sediments underlie loess while overlying glacial till, clayey-loamy sediments or the bedrock.

\section{Loess cover}

The loess cover in the Nałęczów Plateau is up to $30 \mathrm{~m}$ thick. Loess more than $20 \mathrm{~m}$ thick was recorded in a continuous area extending north of the Bystra and Ciemięga valleys where it covers a glacigenic sediment accumulation zone formed during the recession phase of the Odranian Glaciation. Similar thickness was recorded for loess in the western part of the area between the Ciemięga and Czechówka rivers, southern part of the Czechówka catchment near Lublin and Miłocin as well as on the side of the Grodarz valley near Kazimierz Dolny. The loess cover of the Nałęczów Plateau partially mirrors and in many cases conceals the bedrock surface features formed during the recession phases of the Odranian Glaciation. This results from the dynamics of the aeolian sedimentation of the loess cover. Loess reaches maximum thickness in zones where the parent material, consisting of thick series of glacial deposits, has the most varied relief (Harasimiuk, Henkiel 1978).

\section{The distribution of closed depressions in relation to litho-genetical types of sediments underlying the loess}

Analyses indicated that large concentrations of depressions occur in areas where the loess cover is underlain by a thick complex of glacigenic sediments with the predominance of glacial till (Fig. 7). This correlation is clear in the case of areas with a large concentration of closed depressions (closed depressions microregions) such as: Kopanina-Drzewce, Karmanowice, Nałęczów-Czesławi- 


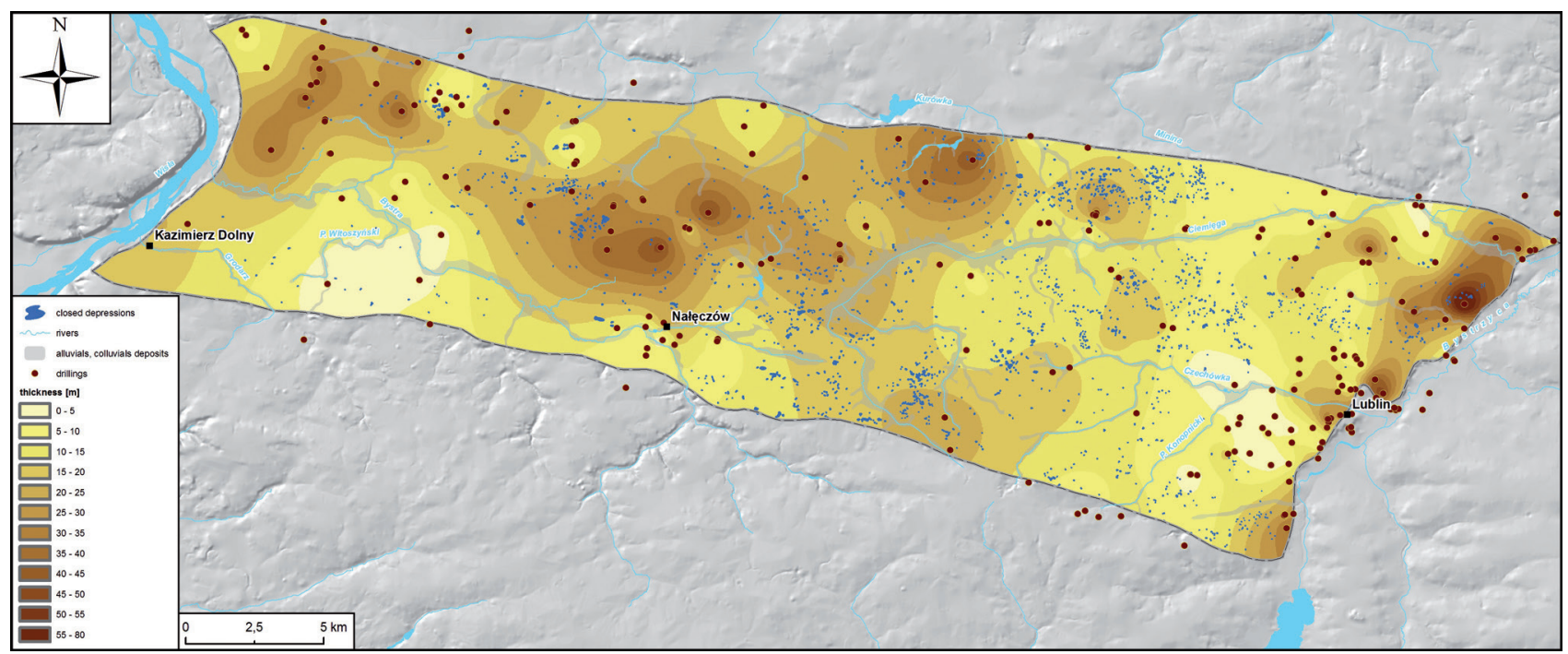

Fig. 7. Distribution of closed depressions in relation to glacigenic sediment thickness

ce, Bogucin-Gutanów, Piotrawin-Smugi (Fig. 5). They are located in an area where the loess covers a zone of Odranian glacial sediment accumulation whose thickness exceeds $20 \mathrm{~m}$ (Fig. 7). A similar correlation occurs also in the case of the eastern part of the Płouszowice-Rudnik microregion and Pliszczyn-Marianówka microregion, both located in the area between the Czechówka and Ciemięga rivers (Fig. 5). In this area, where glacigenic sediments are more than $10 \mathrm{~m}$ thick, local concentrations of closed depressions are up to 25 forms per $\mathrm{km}^{2}$ (Fig. $4,7)$.

Concentrations of closed depressions also occur outside the zone of thick glacial deposits, e.g. the Sadurki-Miłocin and Miłocin Kolonia-Tomaszowice Kolonia closed depressions microregions whose range corresponds to the 5 to $12 \mathrm{~m}$ thick clayey marginal lake sediments occurring in the loess parent material and overlying mainly glacigenic sediments (Fig. 5).

Low concentrations of closed depressions occur in areas where the loess lies directly on the bedrock or with a thin layer (a few metres thick at most) of glacigenic or sandy sediments. An example of this pattern is an area with a small number of depressions, located between the

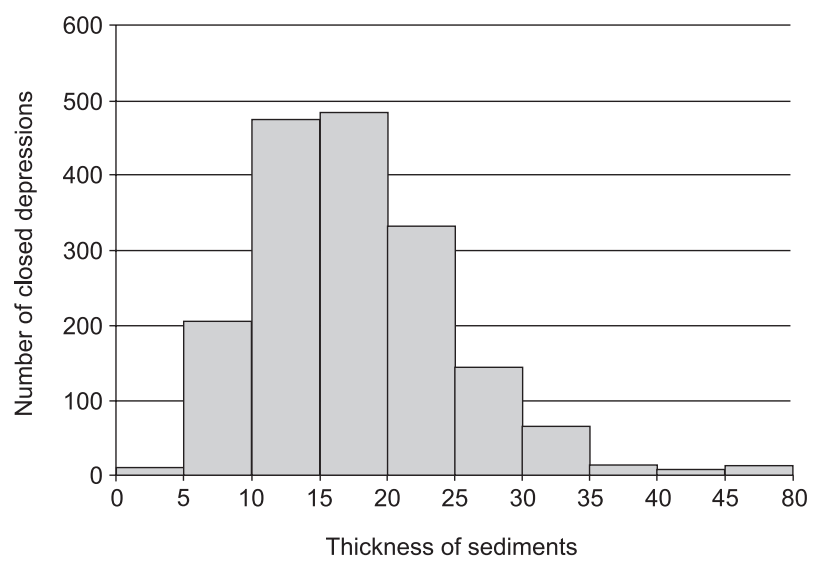

Fig. 8. Number of closed depressions in relation to glacigenic sediment thickness
Bystrzyca and Potok Konopnicki rivers, and between the Bystra and Potok Witoszyński rivers (Fig. 7).

The western part of the Nałęczów Plateau, adjoining the Gap of the Vistula, features a generally low number of depressions despite the presence of glacigenic sediments in its geological structure (Fig. 7). This results from geomorphological determinants modifying the impact of the above-described lithological properties of sediments underlying the loess that are conducive to the formation of closed depressions. A well-developed system of deep erosion-denudation valleys dissected by gully systems functions in this area. Thus, the loess plateau tops - the main areas where closed depressions occur - have a limited range here (Fig. 3).

The statistical analyses revealed that the greatest number of closed depressions occurs in areas where the loess is underlain by a thick complex of glacigenic sediments with the predominance of glacial till, 10 to $25 \mathrm{~m}$ thick (Fig. 8). Pearson's correlation coefficient is 0.59 , documenting the mean value (close to a high value: from 0.6 ) of the correlation between the distribution of closed depressions and thickness of glacigenic sediments in the study area (Fig. 11a). The determination coefficient is 35\% then, which means that the thickness of glacigenic sediments has a $35 \%$ impact on the formation of closed depressions. The regression analysis confirms the correlation between the number of closed depressions and sediment thickness at the significance level of $95 \%$.

\section{The distribution of closed depressions in relation to loess thickness}

Concentrations of closed depressions occur both in areas where the loess is quite thick and not so thick. Areas in the first group have a loess cover more than $12 \mathrm{~m}$ thick (Fig. 9). They include closed depressions microregions located in the western part of the Odranian marginal zone such as: Klementowice-Zażuk, Karmanowice, Kopanina-Drzewce (Fig. 5, 9). The loess is underlain by a thick 


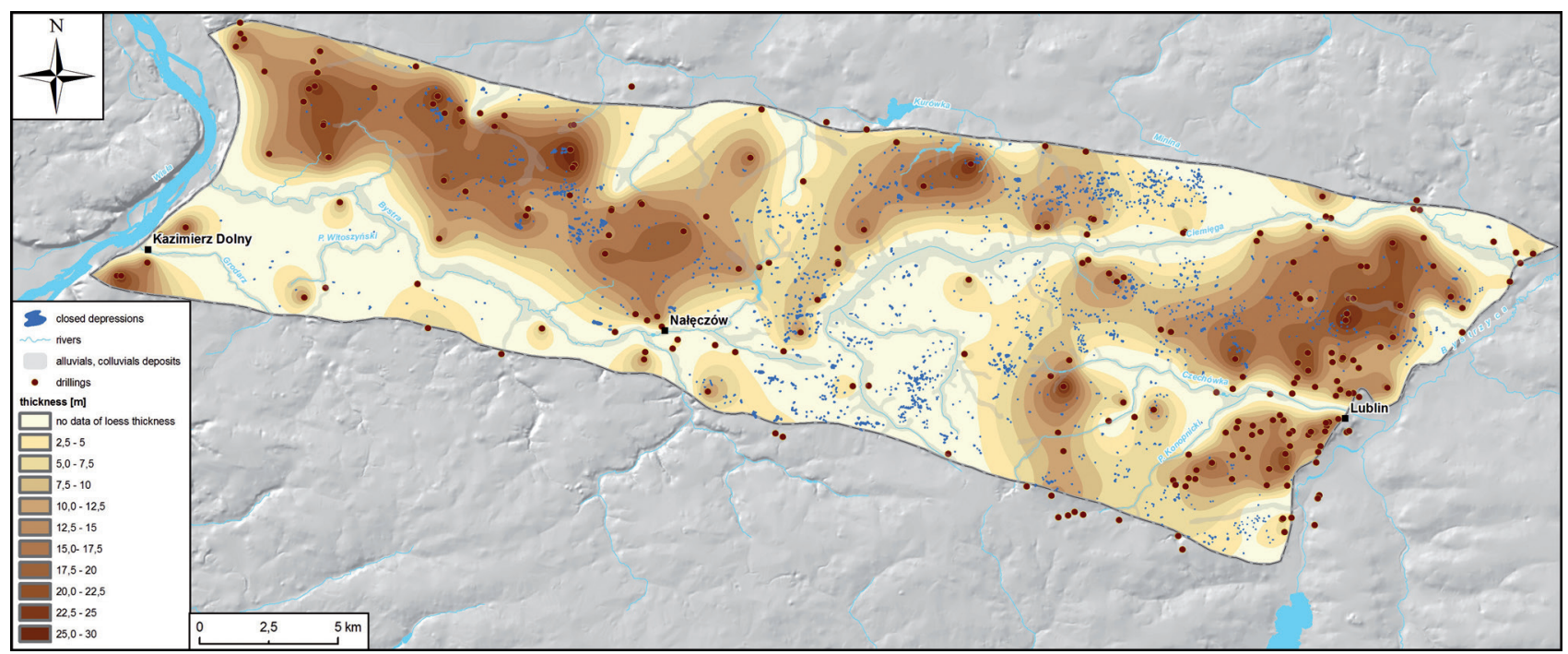

Fig. 9. Distribution of closed depressions in relation to loess thickness

complex of clayey glacial deposits or, as in the case of the first of the microregions above, a thick complex of marginal lake clays. Concentrations of depressions within the thick loess cover also occur in the eastern part of the above-mentioned marginal zone from the recession phase where the Bogucin-Gutanów and Piotrawin-Smugi closed depressions microregions are located (Fig. 5, 9). Furthermore, concentrations of depressions accompanying the thick loess covers also occur within the extensive Płouszowice-Rudnik microregion (Fig. 5, 9).

Regardless of the thick loess cover, few closed depressions were recorded in the eastern part of the area between the Czechówka and Bystrzyca rivers (Fig. 9). A similar pattern can be observed in the zone extending along the Gap of the Vistula.

A thin loess cover occurs in the area between the Ciemięga and Bystra rivers, reaching a few meters at most (up to $5 \mathrm{~m}$ in the few profiles located there). At the same time, the area abounds in closed depressions (Fig. 4). Two big closed depressions microregions are located here: Sadurki-Miłocin and Kolonia Tomaszowice-Kolonia Miłocin (Fig. 5) where a thin loess cover overlies

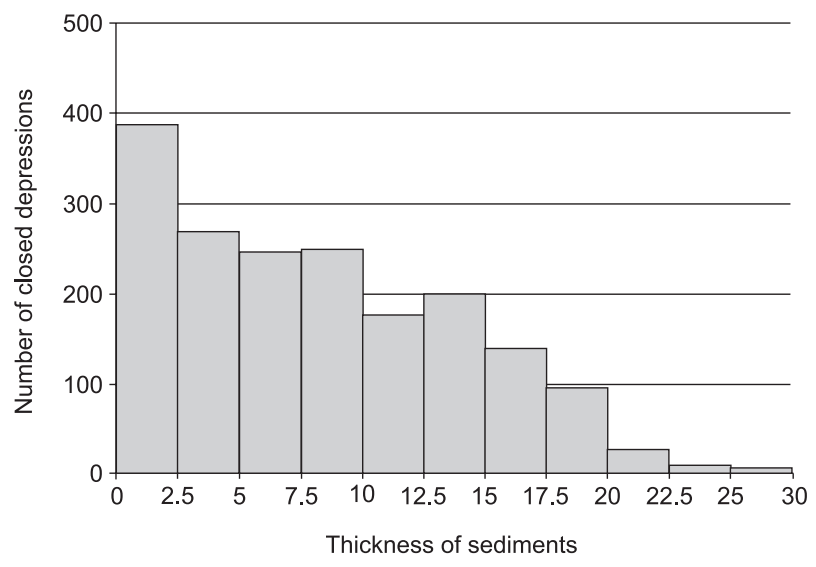

Fig. 10. Number of closed depressions in relation to loess thickness thick marginal lake clays originating in the Odranian Glaciation.

The distribution of closed depressions is poorly correlated with loess thickness. Pearson's correlation coefficient is 0.4 (Fig. 11b), which means that the thickness of the loess has a $20 \%$ impact and is merely one of many factors impacting the number of closed depressions. This is confirmed by the result obtained for linear correlation: it indicates the lack of a statistically significant correlation
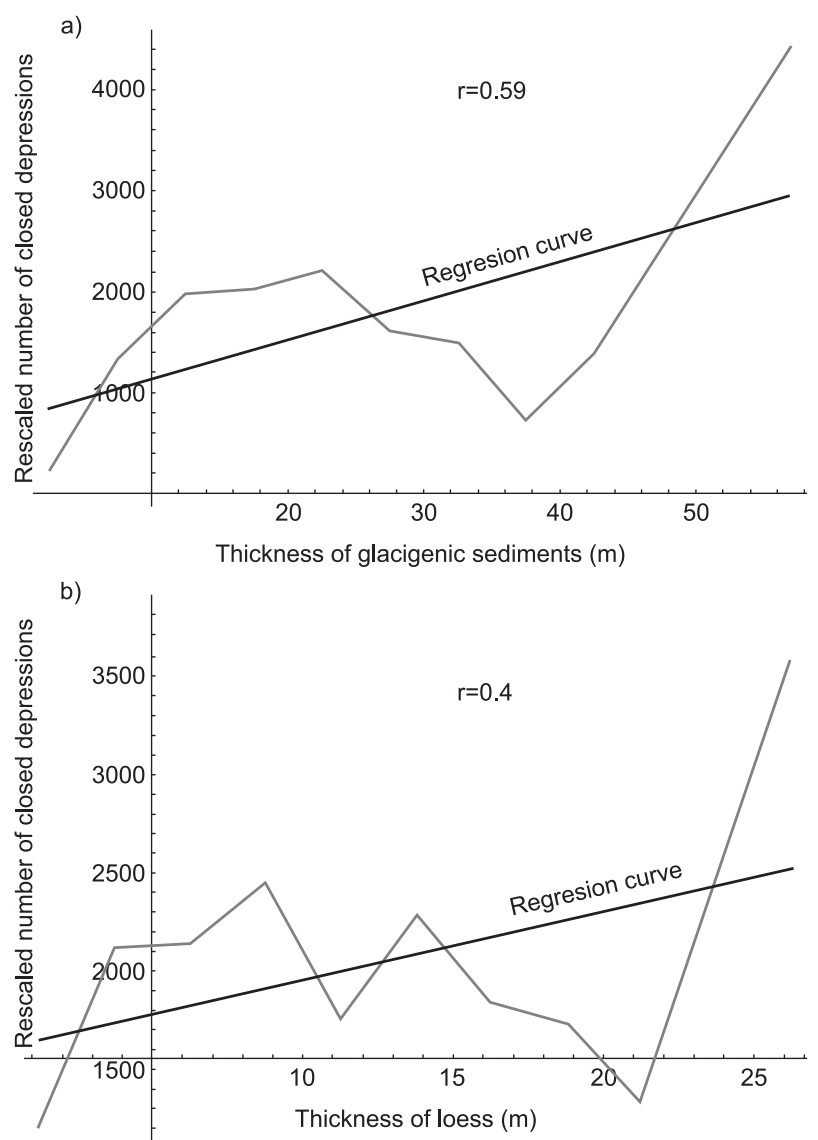

Fig. 11. Pearson's correlation coefficient (r) 
between loess thickness and the number of closed depressions at the significance level of $95 \%$.

The lack of a clear correlation between the loess cover thickness and number of closed depressions is also illustrated by Fig. 10. However, it should be noted that areas with the thickest loess cover (more than $20 \mathrm{~m}$ ) feature a relatively small number of depressions.

\section{Problems of the origin of the closed depressions and factors controlling their spatial distribution}

The documented correlations between the distribution of closed depressions and the main litho-genetical types of sediments underlying the loess suggest a significant impact of the above-mentioned factor on the origin of the forms under study. The essence of these correlations is based on the different hydrogeological properties of the individual litho-genetical types of sediments underlying the loess. By shaping the conditions of water drainage, these properties could have controlled the formation process of the depressions under specific (periglacial) climate conditions. Closed depressions are the most abundant in the eastern part of the region where the loess is underlain by almost impermeable sediments such as thick complexes of glacigenic sediments with the predominance of glacial till and marginal clays. Furthermore, these areas show a relatively poor development of the polygenetic valley system; hence they are characterised by permanently poor drainage conditions. The above-mentioned hydrogeological conditions along with poor water drainage may have resulted in the functioning of unique conditions of permafrost degradation in the Late Glacial.

The peculiar distribution of the closed depressions is probably determined by the joint impact of geological factors (lithology of the sediments underlying the loess) and geomorphological factors determining the drainage of waters originating from the melting permafrost. Some areas in the western part of the Nałęczów Plateau feature a small number of depressions despite the thick glacial complexes underlying the loess. These are areas with a well-developed system of deep polygenetic valleys, frequently dissecting the bedrock. Their presence has a permanent impact on the good water drainage conditions in this area, also in the period of permafrost melting. The drainage conditions are controlled by the location of the base levels of erosion of the main rivers draining the individual parts of the region. For the Bystra catchment, draining the western part of the Nałęczów Plateau, the base level of erosion is the bottom of the Vistula river valley, currently situated about $120 \mathrm{~m}$ a.s.1., in the Late Glacial at about $130 \mathrm{~m}$ a.s.1. (level of the Pleistocene terrace). For the eastern part of the region, drained by the Ciemięga, the base level of erosion is the bottom of the Bystrzyca river valley, situated at 165 $\mathrm{m}$ a.s.1. The present-day elevation gradient, computed as the difference between the highest- and lowest- lying place in the catchment, is $98 \mathrm{~m}$ for the Bystra and $54 \mathrm{~m}$ for the Ciemięga. The huge difference between the gradients of either catchment (one is nearly twice as high as the oth- er) indirectly illustrates the dissection depth in both areas and, consequently, the groundwater drainage capacity in the two major catchments of the region. In the light of the studies on the spatial distribution of the closed depressions, the problem of their origin requires further studies specially designed for the purpose.

\section{Conclusions}

1. The analysis of the distribution of the closed depressions in the Nałęczów Plateau reveals the existence of zones described as closed depressions microregions, marked by high concentrations of closed depressions.

2. The location of areas with high concentrations of closed depressions does not depend on the thickness of the loess cover but is clearly correlated with the lithological properties of the sediments underlying the loess that shapes the local hydrogeological conditions.

3 . The distribution of areas of concentration of depressions corresponds to the presence of a thick complex of glacigenic sediments with the predominance of glacial till and a complex of clayey (limniglacial) sediments underlying the loess. These areas are characterised by peculiar hydrogeological conditions, which could enable creation of closed depression especially under periglacial conditions.

4. Zones with low concentrations of closed depressions (fewer than 10 forms per $\mathrm{km}^{2}$ ) correspond to areas where glacial and limniglacial sediments do not occur under loess cover, and the loess lies directly on the bedrock consisting of opokas or thin sandy-gravelly fluvio-glacial sediments.

5. The distribution of closed depressions and their correspondence with the lithological properties of the sediments underlying the loess indicates the role of this factor in controlling the development of closed depressions.

6. The results of the present analyses suggest that the discussion on the origins and development conditions of closed depressions in loess areas should be reopened.

\section{Acknowledgements}

The research project was financially supported by the National Science Centre - project 2012/07/B/ST10/04164: The origin and evolution of closed depressions in the loess area of the Lublin Upland and their importance for the reconstruction of postglacial morphogenesis of the loess covers.

\section{References}

Butrym A., Harasimiuk M., Henkiel A.., 1980. Szczegółowa Mapa Geologiczna Polski ark. Lublin. PIG, Warszawa.

Czarnecki R., Lewartowska-Urbańska M., 1987. Wymoki okolic Sandomierza. Przegląd Geograficzny LIX(3): 385-397. 
Czarnecki R., Solnceva N. P., 1992. Wymoki okolic Sandomierza (cz. II.). Przegląd geograficzny LXIII(1-2): 143-149.

Etienne D., Ruffaldi P., Goepp S., Ritz F., Georges-Leroy M., Pollier B., Dambrine E., 2011. The origin of closed depressions in Northeastern France: A new assessment. Geomorphology 126: 121-131.

Gillijns K., Poesen J., Deckers J., 2005. On the charakteristics and origin of closed depression in loess-derived soils in Europe - a case study from central Belgium. Catena 60: 43-58.

Harasimiuk M., 1987. Lithologic Properties as Indices of the Sedimentation Conditions of the vistulian Loesses in the Eastern Part of the Nałęczów Plateau (SE Poland). Annales UMCS, sec. B XLI(11): 179-202.

Harasimiuk M., Henkiel A., 1976. Osobliwości pokrywy lessowej zachodniej części Płaskowyżu Nałęczowskiego. Z badań czwartorzędu w Polsce t. 18. Wyd. Geol., Warszawa: 177-181.

Harasimiuk M., Henkiel A., 1978. Wpływ budowy geologicznej i rzeźby podłoża na ukształtowanie pokrywy lessowej w zachodniej części Płaskowyżu Nałęczowskiego. Annales UMCS, sec. B XXX/XXXI: 55-80.

Harasimiuk M., Jezierski W., 2001. Profil lessów w Skowieszynie na Wyżynie Lubelskiej. In: H. Maruszczak (ed.), Podstawowe profile lessów w Polsce t. II. Wyd. UMCS, Lublin: 93-100.

Harasimiuk M., Superson J., Nowak J., 2008. Budowa geologiczna i rzeźba terenu. In: S.Uziak, R.Turski (eds.), Środowisko przyrodnicze Lubelszczyzny. LTN. Lublin: 9-73.

Harasimiuk M., Gawrysiak L., 2012. Spatial diversity of gully density of the Lublin Upland and Roztocze Hills (SE Poland). Annales UMCS, sec. B LXVII(1): 27-43.

Jahn A., 1956. Wyżyna Lubelska. Rzeźba i czwartorzęd. PWN, Warszawa: 453.

Kołodyńska-Gawrysiak R., Chabudziński Ł., 2012. Cechy morfometryczne oraz rozmieszczenie zagłębień bezodpływowych Płaskowyżu Nałęczowskiego (Wyżyna Lubelska, E Polska). Annales UMCS, sec. B LXVII(1): 45-61.

Kołodyńska-Gawrysiak R., Mroczek P., Chabudziński Ł. 2013. Closed depressions in the Prehistoric loess landscape and their influence on settlement location in the light of selected examples from the Nałęczów Plateau (Lublin Upland, E Poland). Archeologia Polona 49: $37-54$.

Konecka-Betley K., Maruszczak H., 1993. Rozwój holoceńskiej pedogenezy w wymokach obszarów lessowych okolic Lublina. Roczniki Gleboznawcze 34(3/4): 153-163.

Makeev A., 2009. Pedogenic alteration of eolian sediments in the upper loess mantles of the Russian Plain. Quaternary International 209: 79-94.

Maruszczak H., 1954. Werteby obszarów lessowych Wyżyny Lubelskiej. Annales UMCS, sec. B VIII: 123-237.

Maruszczak H., 1964. Mapa geomorfologiczna województwa lubelskiego 1: 300 000. Zakład Geoekologii i Paleogeografii UMCS, Lublin.

Maruszczak H., 2001. Podstawowe profile lessów w Polsce. Cz. II: 162.

Pissart A., 1958. Les depressions fermees de la region Parisienne, la problem de leur origine. Revue de Geomorphologie Dynamique 9: $73-83$.

Prince HC., 1961. Some reflections on the origin of hollows in Norfolk compared with those in the Paris region. Revue de Geomorphologie Dynamique 12: 110-117.

Stankowski W., 2012. Transformation from natural (thermal contraction) to anthropogenic (resource exploitation) depressions in the Krotoszyn-Koźmin-Raszków area (Polish Lowland). Geologos 18(1): 43-50.

Wojtanowicz J., 1997. Geneza i wiek jeziorek grodziskich. In: M.Łanczont (ed.), Glacjał i peryglacjał Kotliny Sandomierskiej i Przedgórza Karpat w okolicy Przemyśla: seminarium terenowe. Kraśniczyn 22-24 września 1997, Zakład Geografii Fizycznej i Paleogeografii, UMCS: 113-117.

Vanwalleghem T., Poesen J., Vitse I., Bork H. R., Dotterweich M., Schmidtchen G., Deckers J., Lang A., Mauz B., 2007. Origin and evolution of closed depression in central Belgium, European loess belt. Earth Surface Processes and Landforms 32: 574-586.

Zanin G. W 1952. O proischożdienii zapadin Oksko-Donskoj rawniny. Materiały po geomorfologii i paleogieografii SSSR. Wyp. 6, Moskwa: $33-57$. 